\title{
Child tuberculosisin Respira Lung Hospital, Yogyakarta: demographic and clinical profiles
}

\author{
Stefani Candra Firmanti ${ }^{1}$, Rina Triasih ${ }^{2}$ \\ ${ }^{1}$ Departmentof Microbiology, Faculty of Medicine, Universitas Diponegoro, ${ }^{2}$ Departmentof \\ Paediatrics, Dr. Sardjito General Hospital/Faculty of Medicine,Universitas \\ Gadjah Mada
}

DOI: http://dx.doi.org/10.19106/JMedScieSup0050012018010

\section{ABSTRACT}

Tuberculosis (TB) remains a significant source of morbidity and mortality among children in endemic settings. Demografic and clinical profiles of children with TB in Yogyakarta have not been well documented. A total of 80 children with TB were diagnosed with TB during the study period. There were $41(51.2 \%)$ females and $39(48.8 \%)$ males. The case finding of child TB cases has been increasing from 20 cases in 2014, 28 casesin 2015, and 32 cases in 2016. The majority of the children (89.3\%) aged less than 5 years. The most common symptoms were cough $50(62.5 \%)$, followed by weight loss $45(56.3 \%)$, and fever $28(35 \%)$. Contact with a TB case was identified in $46(57.5 \%)$ children. Mantoux test was done in 76 (95\%) children with positive result documented in $61(76.3 \%)$ children. Chest X-ray was done in $54(67.5 \%)$ children, of which $52(65 \%)$ chest $\mathrm{X}$ - rays showed suggestive of TB. Confirmed diagnosis (bacteriology) was only documentd in one child (1.25\%).

Keywords: children - tuberculosis - clinical - demographic

*corresponding author: stefanisuryanto@gmail.com 